
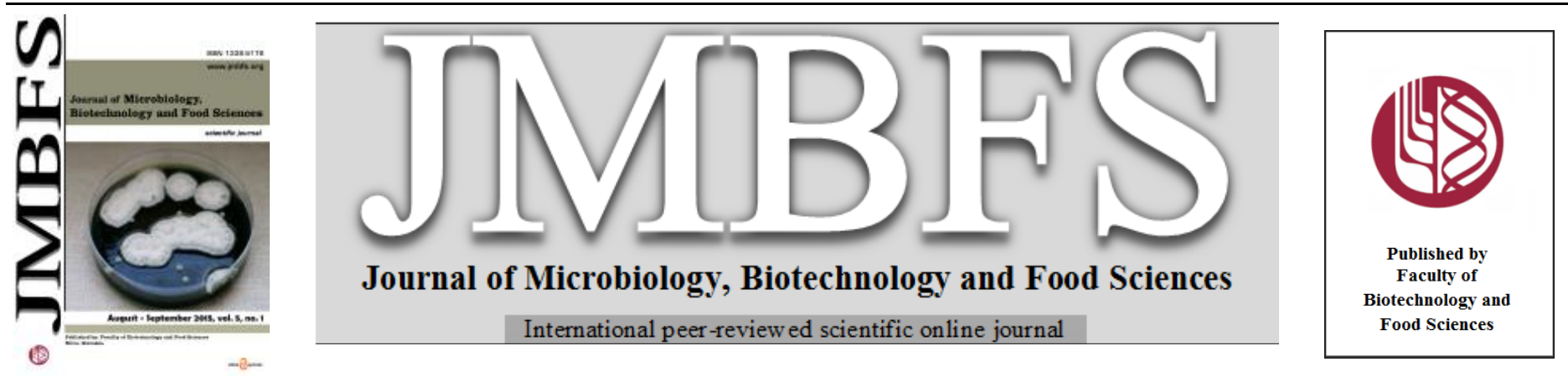

\title{
SEASONAL VARIATION OF SOME SPERM PARAMETERS IN BOARS HOUSED IN STANDARDIZED CONDITIONS
}

\author{
Iulian Ibănescu ${ }^{* 1}$, Petru Roşcal ${ }^{1}$ Ioana Sfartz ${ }^{1}$, Gelu Pavel ${ }^{2}$ Dan Drugociu ${ }^{1}$
}

\author{
Address(es): \\ ${ }^{1}$ University of Agricultural Sciences and Veterinary Medicine of Iasi, Faculty of Veterinary Medicine, Department of Clinics, Aleea M. Sadoveanu no. 3, 700490, Iasi, \\ Romania. \\ ${ }^{2}$ Suinprod Roman, Traian 611040, Romania.
}

*Corresponding author: iulian.ibanescu@yahoo.com

doi: 10.15414/jmbfs.2015.5.1.52-54

\section{ARTICLE INFO}

Received 12. 5. 2015

Revised 28. 5. 2015

Accepted 10. 6. 2015

Published 1. 8. 2015

Regular article

open $\bigodot_{\text {ACCESS }}$

\begin{abstract}
Spermatogenesis in boar can be influenced by many factors, which will determine a variation of seminal parameters. A better knowledge of the opportunities to control the variation of semen quantity and quality can increase the efficiency of swine reproduction units.

The aim of this study was to examine the seasonal variation of semen, in order to offer a solution against "seasonal infertility" in pigs.

The study was conducted on a number of 537 ejaculates, from 31 Pietrain boars housed in standardized conditions in terms of temperature, humidity and light schedule. Semen was collected by manual method, and examined using the beaker, and CASA system (CEROS II). The results, expressed as mean values, were as following: Volume showed higher values in the summer (218.7 ml) and lower in the autumn $(155.7 \mathrm{ml})$; Total number of spermatozoa/ejaculate was higher in the summer $\left(95.9 \times 10^{9}\right)$ and lower in the winter $\left(74.3 \times 10^{9}\right)$; Semen concentration was higher in the autumn $\left(571.6 \times 10^{6} / \mathrm{ml}\right)$ and lower in the summer $\left(454.8 \times 10^{6} / \mathrm{ml}\right)$; Total number of motile spermatozoa/ejaculate showed higher values in summer $\left(79.5 \times 10^{9}\right)$ and lower in winter $\left(65.4 \times 10^{9}\right)$; \% of Total motility was higher in the winter $(87.9 \%)$ and lower in the summer (82.3\%); Total number of progressive spermatozoa/ejaculate was higher in summer $\left(52.7 \times 10^{9}\right)$ and lower in autumn $\left(44.2 \times 10^{9}\right) ; \%$ of Progressive motility was higher in winter $(61.4 \%)$ and lower in autumn $(52.3 \%)$. The results contradict those of other authors, who studied the semen from boars held in classic conditions. This fact suggests that the standardization of exploitation conditions of boars by maintaining a controlled climate in the farm can reduce the effects of heat stress on spermatogenesis during summer, offering a great opportunity against seasonal infertility and high variations of semen parameters during a year.
\end{abstract}

Keywords: Boar, sperm, variation, standardized housing conditions

\section{INTRODUCTION}

Spermatogenesis in boar can be influenced by many factors, which will determine a variation of seminal parameters.

Seasonal variation of boar semen was largely debated, representing a real issue with economic impact. Season seems to have an influence on swine reproduction, affecting the seminal parameters in boar (Smital, 2009) and the main indices of fertility in sows (Bertoldo et al, 2011) but also other indicators such as the timing of post-weaning oestrus, sows weaned in the summer months taking longer to return to oestrus than sows weaned at other times of the year (Claus and Weiler, 1985).

Various authors have obtained different results, but most agreed that during the summer and early autumn there is a decrease in the biological value of semen, with lower values obtained within its quality examination.

This phenomenon is recognized worldwide and is called seasonal or summer infertility (Peltoniemi et al., 1999) and as causes for seasonal variation of semen were indicated photoperiod (Andersson, 2000; Sancho et al, 2004; Knecht et al., 2013), temperature (Kunavongkrit et al., 2005), humidity (Suriyasomboon, et al, 2004) or the presence of an ancestral mechanism inherited from wild boar (Tast $\boldsymbol{e t}$ al., 2001, Cheon $\boldsymbol{e t}$ al, 2002), species in which the reproduction is seasonal, with mating occurring mostly in late autumn or early winter (Mauget., 1982), a period that coincides with an increase in the quantity and quality of semen (Kozdrowski and Dubiel, 2004).

Also, seasonal variation of seminal parameters in boar was correlated with the variation of serum testosterone concentrations, some studies suggesting that when serum testosterone concentrations is higher among seasons, semen volume, sperm concentration and also frozen-thawed sperm viability are higher as well (Cheon et al, 2002; Park and Yi, 2002).

Although the main seminal indicators determined within the general examination of raw boar semen (volume, concentration, motility, total number of spermatozoa/ejaculate) proved to have low or no predictive value on the litter size or pregnancy rate (Schulze et al., 2013), a better knowledge of the opportunities to control the variation of these parameters would be of a great help for the semen production centers, which are sometimes forced to keep additional boars to compensate the seasonal fluctuations (Colenbrander and Kemp, 1990). Nowadays, many pig farms attempt to provide standardized housing conditions for animals, with minimizing variations in microclimate and maintaining the temperature, light regime, humidity and ventilation between optimum limits in order to avoid the stress caused by some factors such as extreme temperature, high humidity and strong air currents. Thus, the seasonal variations in semen parameters that depend on the microclimate may be minimized.

The objective of our study was to examine the seasonal variation of seminal parameters in boars housed in standardized conditions, in order to determine whether or not this housing system could be a solution against "seasonal infertility" in pigs.

\section{MATERIAL AND METHODS}

\section{Boars}

The semen originated from 31 clinically healthy and sexually mature Pietrain boars, aged between 8 months and 2.5 years, from a modern, recently built unit, specialized in porcine reproduction.

Throughout the study, boars were housed under standardized conditions. The temperature was maintained throughout the year around $18^{\circ} \mathrm{C}$ using heating in winter and cold water sprinklers in summer. Light was provided by artificial plants and kept for 11 hours a day, regardless of the season. Food was prepared following the same recipe throughout the study and its administration was performed automatically by a special installation. Water was given ad libitum.

\section{Semen collection and examination}

Semen collection was performed using manual method with double glove (Bogdan, 1999; Ciornei, 2012) on a dummy, with an interval of at least 7 days between two successive collections from the same boar.

After collection, the main seminal parameters were determined, as follows: volume - using the beaker; semen concentration, total number of sperm/ejaculate, 
total motility, total number of motile spermatozoa/ejaculate, progressive motility, total number of progressive spermatozoa/ejaculate - using a computer assisted sperm analyzer, namely CEROS II device (IMV Technologies, L'Aigle, France). Only the ejaculates with at least $60 \%$ total motility were recorded and processed, the rest of them being discarded.

The duration of the study was 12 months, from $1^{\text {st }}$ December 2012 to $30^{\text {th }}$ November 2013, including all the four seasons specific to temperate climate: winter (December, January, February), spring (March, April, May), summer (June, July, August) and autumn (September, October, November).

\section{Statistical analysis}

The data were statistically processed using IBM SPSS ${ }^{\circledR}$ Statistics program, version 21 (IBM ${ }^{\circledR}$ Corporation, Chicago, IL, USA). Results are presented as mean values and standard deviation (SD). To highlight significant differences, the One-Way ANOVA test was used and statistically significance was set at $p$ $<0.05$.

\section{RESULTS AND DISCUSSION}

\section{Seasonal variation of volume}

As shown in Table 1, the average seasonal values of volume ranged from 155.74 $\mathrm{ml}$ in autumn to $218.75 \mathrm{ml}$ in summer.

Table 1 Mean values of ejaculate volume, according to the season

\begin{tabular}{ccccc}
\hline & \multicolumn{4}{c}{ Season } \\
\cline { 2 - 5 } & Winter & Spring & Summer & Autumn \\
\hline Mean (ml) & $166.01^{\text {ad }}$ & $194.69^{\mathrm{b}}$ & $218.75^{\mathrm{c}}$ & $155.74^{\text {ad }}$ \\
Std. Deviation & 47.446 & 45.056 & 54.922 & 55.682 \\
\hline
\end{tabular}

Different letters in the same row indicate significant differences between values $(\mathrm{p}<0.05)$

Semen volume is represented by approximately $93 \%$ of seminal plasma (Ciornei, 2012), which is produced by accessory glands. In our study, the highest value of the volume was obtained in June through August, with significant differences from other periods suggesting that the activity of these glands was greater in summer than in other seasons. The results contradict those obtained by other authors. For example, Janett $\boldsymbol{e t}$ al, (2005) observed significantly higher values in autumn, while Cheon et al (2002) and Suriyasomboon et al, (2004) reported the lowest values in summer. Lawrence $\boldsymbol{e t}$ al. (1970) obtained higher values for semen volume in the period from October to December, during which the temperature did not exceed $76.8^{\circ} \mathrm{F}\left(24.89^{\circ} \mathrm{C}\right)$.

\section{Seasonal variation of semen concentration}

Semen concentration ranged from $454.89 \times 10^{6} / \mathrm{ml}$ in summer and $571.62 \times 10^{6} / \mathrm{ml}$ in autumn (table 2).

Table 2 Mean values of semen concentration, according to the season

\begin{tabular}{ccccc}
\hline & \multicolumn{4}{c}{ Season } \\
\cline { 2 - 5 } & Winter & Spring & Summer & Autumn \\
\hline Mean $\left(\times 10^{6} / \mathrm{ml}\right)$ & $467.49^{\text {abc }}$ & $466.90^{\text {abc }}$ & $454.89^{\text {abc }}$ & $571.62^{\mathrm{d}}$ \\
Std. Deviation & 128.53 & 113.73 & 121.52 & 159.62 \\
\hline
\end{tabular}

Different letters in the same row indicate significant differences between values
$(\mathrm{p}<0.05)$

Except autumn, there were no significant differences between seasons. One can see that between September and November was recorded the highest mean for semen concentration, but also the highest standard deviation, suggesting greater variability of values.

The higher concentration from autumn can be explained by the lower volume in the same period. Thus, the results might suggest that the process of spermatogenesis remained constant, the concentration being modulated indirectly by the volume, more exactly the glands activity, which increased the number of sperm per unit volume during autumn indirectly, by reducing the amount of seminal plasma.

Our results were in a high manner different from those obtained in other studies, where significantly lower values were observed during autumn (Syring, 2008; Petrocelli et al., 2015). In the study mentioned first, the author observed a clear influence of the season but also of the ambient temperature on the seminal parameters.

\section{Seasonal variation of total number of spermatozoa}

The total number of spermatozoa/ejaculate (TSE) is the parameter that reflects the most accurately the spermatogenesis activity. This parameter has showed significantly higher values during the summer season (Table 3). Thus, it appears that increased activity of accessory glands from June through August was accompanied by an increase in spermatogenesis. The opposite is the winter season, while between spring and autumn no significant differences were observed.

Table 3 Mean values of total number of sperm/ejaculate, according to the season

\begin{tabular}{ccccc}
\hline & \multicolumn{4}{c}{ Season } \\
\cline { 2 - 5 } & Winter & Spring & Summer & Autumn \\
\hline Mean $\left(\times 10^{9}\right)$ & $74.30^{\text {a }}$ & $87.66^{\text {bd }}$ & $95.91^{\mathrm{c}}$ & $84.71^{\text {bd }}$ \\
Std. Deviation & 19.84 & 17.44 & 24.92 & 29.09 \\
\hline $\begin{array}{l}\text { Different letters in the same row indicate significant differences between values } \\
(\mathrm{p}<0.05)\end{array}$
\end{tabular}

The results contradict those obtained in previous studies (Janett $\boldsymbol{e t}$ al, 2005), in which the total sperm number was significantly lower in spring and summer than in autumn and winter. Also, these authors, reported lower percentage of morphologically normal sperm during summer.

Another study observed higher production of spermatozoa in autumn and winter and low production in summer (Ciereszko et al, 2000). The authors claimed that the changes might have been caused by disturbances to spermatogenesis due to high temperatures during the summer and that the variation of this parameter was parallel to the monthly changes in acrosin activity between November and March.

\section{Seasonal variation of total and progressive motility}

One of the main quality indicators to be taken into account within the general examination of semen is motility, which reflects the ability of sperm to reach the fertilization spot. If the value of motility is below certain standard limits, the whole ejaculate is discarded. As mentioned above, the acceptance threshold in this study was set to $60 \%$ total motility.

Total motility (Tmot) ranged from $82.39 \% \pm 8.98$ in summer to $87.94 \% \pm 6.11$ in winter (Table 4). Although apparently in summer were recorded lower values, it can be observed that the differences between the mean values of summer compared to spring and autumn are statistically insignificant $(p<0.05)$, suggesting that standardization of housing conditions helped avoiding the heat stress during summer, being previously demonstrated that temperatures above $30^{\circ} \mathrm{C}$ lead to a clear decline in semen quality (Schnurrbusch et al, 2002).

The season of collection is one of the main parameters influencing the value of semen motility in boar (Ibănescu $\boldsymbol{e t} \boldsymbol{a l}, \mathbf{2 0 1 4}$ ), but in the present study this influence was minimal, with no significant differences between three seasons. The only season that showed a statistically different mean was winter, during which a lower variability of values was also recorded.

Table 4 Mean values of total and progressive motility, according to the season

\begin{tabular}{lccccc}
\hline & & \multicolumn{4}{c}{ Season } \\
\cline { 3 - 6 } & & Winter & Spring & Summer & Autumn \\
\hline \multirow{2}{*}{ Tmot $(\%)$} & Mean & $87.94^{\text {a }}$ & $85.05^{\text {bcd }}$ & $82.39^{\text {bcd }}$ & $83.35^{\text {bcd }}$ \\
& Std. Dev. & 6.11 & 8.10 & 8.98 & 8.12 \\
\hline \multirow{2}{*}{ Pmot $(\%)$} & Mean & $61.41^{\text {a }}$ & $54.25^{\text {bcd }}$ & $54.14^{\text {bcd }}$ & $52.31^{\text {bcd }}$ \\
& Std. Dev. & 9.38 & 13.59 & 13.04 & 10.68 \\
\hline
\end{tabular}

Different letters in the same row indicate significant differences between values $(\mathrm{p}<0.05)$

An identical appearance can be observed for progressive motility (Pmot), which in the case of computerized semen analysis indicate the percentage of spermatozoa with forward movements (table 4).

The higher values were recorded during winter $(61.41 \pm 9.38)$. However, one can note the lack of significant differences between all the other three seasons ( $\mathrm{p}$ $<0.05$ ), unlike other studies that have reported significantly higher values during spring (Syring, 2008) or winter and spring (Barranco et al, 2013). The latter also observed that the spermatozoa from ejaculates collected during summer and, to a lesser extent, also in autumn, are more sensitive to cryopreservation than those from ejaculates collected during winter and spring. Murase $\boldsymbol{e t} \boldsymbol{a l}$. (2007) reported the lowest percentage of motile spermatozoa $(\mathrm{p}<0.05)$ in the months of late summer and early autumn. In their study, this period coincided with the highest ambient temperatures and relatively high humidity and also offered the highest agglutination score, lowest percentage of spermatozoa with intact acrosomes and highest percentage of spermatozoa with abnormal morphology. 
Seasonal variation of total number of motile sperm within the entire ejaculate, and of total number of progressive sperm within the entire ejaculate

These two parameters reflect both the intensity of sperm formation and efficiency of their maturation.

The total number of motile spermatozoa (TMS) showed higher values in summer, but the differences were not significant compared to spring and autumn (table 5).

Table 5 Mean values of TMS and TPS, according to the season

\begin{tabular}{cccccc}
\hline & & \multicolumn{4}{c}{ Season } \\
\cline { 3 - 6 } & & Winter & Spring & Summer & Autumn \\
\hline \multirow{2}{*}{ TMS $\left(\times 10^{9}\right)$} & Mean & $65.42^{\mathrm{a}}$ & $74.68^{\mathrm{bd}}$ & $79.51^{\mathrm{cd}}$ & $71.46^{\text {ad }}$ \\
& Std. Dev. & $18.11^{\mathrm{ab}}$ & $16.61^{\mathrm{bc}}$ & $24.17^{\mathrm{c}}$ & 27.11 \\
\hline \multirow{2}{*}{$\operatorname{TPS}\left(\times 10^{9}\right)$} & Mean & $45.71^{\mathrm{b}}$ & $47.82^{\mathrm{bc}}$ & $52.74^{\mathrm{c}}$ & $44.20^{\mathrm{bd}}$ \\
& Std. Dev. & $14.14^{\mathrm{N}}$ & 16.09 & 21.56 & 17.68 \\
\hline
\end{tabular}

Different letters in the same row indicate significant differences between values $(\mathrm{p}<0.05)$

Remarkably, winter offered significant lower values for TMS, compared to other seasons, although the value of total motility was the highest. This fact is explained by the low value of TSE recorded in the same period, and suggest that TMS is modulated rather by the total number of spermatozoa within the ejaculate than by the percentage of total motility.

As for the total number of progressive sperm (TPS), significant higher values was recorded during summer compared to other seasons, which can be correlated with the higher values of TSE during the same period of time. All the other seasons showed low or no significant differences between the average values for TPS.

\section{CONCLUSION}

During our study, the influence of the season on the main seminal parameters in boar was less visible than in other studies performed on this subject. Even though some variances of values between the seasons could be observed, they were of a lower significance, and could have been caused by other factors affecting the semen production, for example boar age or subclinical infections. Moreover, while the majority of authors claim that during the summer the semen quantity is lower, we obtained higher values for semen volume and total number of spermatozoa/ejaculate. These facts suggest that the standardization and optimization of the microclimate within the farm can reduce the heat stress on spermatogenesis in the summer, offering a great solution against seasona infertility in pigs. Further studies are recommended in order to observe if this housing system is of any help in terms of other seminal parameters also.

Acknowledgments: This study was published under the frame of European Social Fund, Human Resources Development Operational Programme 2007 2013, project no. POSDRU/159/1.5/S/132765.

The authors want to thank SuinProd S.A. Roman, Romania, for their support during the study.

\section{REFERENCES}

ANDERSSON H., 2000. Photoperiodism in Pigs: Studies on Timing of Male Puberty and Melatonin. Doctoral Thesis. Swedish University Agricultura Science, Uppsala, Sweden.

BARRANCO ISABEL, ORTEGA MARIA D., MARTINEZ-ALBORCIA MARIA J., VAZQUEZ JM., MARTINEZ E A., ROCA J., 2013. Season of ejaculate collection influences the freezability of boar spermatozoa. Cryobiology, 67(3), 299-304. http://dx.doi.org/10.1016/j.cryobiol.2013.09.001

BERTOLDO M.J., HOLYOAKE P.K., EVANS G., GRUPEN C.G., 2012 Seasonal variation in the ovarian function of sows. Reprod. Fertil. Dev., 24(6), 822-834. http://dx.doi.org/10.1071/rd11249

BOGDAN AT, 1999 - Tratat de reproducţie şi însămânţări artificiale la suine. Editura Tehnică Agricolă, Bucureşti.

CHEON Y.M., KIM H.K., YANG C.B., YI Y.J., PARK C.S., 2002. Effect of Season Influencing Semen Characteristics, Frozen-Thawed Sperm Viability and Testosterone Concentration in Duroc Boars. Asian-Aust. J. Anim. Sci., 15(4), 500-503. http://dx.doi.org/10.5713/ajas.2002.500
CIERESZKO A., OTTOBRE J.S., GLOGOWSKI J., 2000. Effects of season and breed on sperm acrosin activity and semen quality of boars. Anim. Reprod. Sci. 64(1-2), 89-96. http://dx.doi.org/10.1016/s0378-4320(00)00194-9

CIORNEI Ş.G., 2012. Materialul seminal de vier şi biotehnologii de reproducție la suine. Editura "Ion Ionescu de la Brad", Iaşi. ISBN: 978-973-147-102-0.

CLAUS, R., WEILER, U., 1985. Influence of light and photoperiodicity on pig prolificacy. J. Reprod. Fert. 33, 185-197, Suppl.

COLENBRANDER B. AND KEMP B. 1990. Factors influencing semen quality in pigs. J. Reprod. Fertil. 40, 105-115, (Suppl.)

IBĂNESCU I., DRUGOCIU D., ROŞCA P., SFARTZ Ioana, 2014. Factors influencing sperm motility in boar. Lucrări Știinţifice USAMV Iaşi - seria Medicină Veterinară, 57(1-2):116-126.

JANETT F., FUSCHINI E., KEO S., HÄSSIG M., THUN R, 2005. Seasonal changes of semen quality in the boar. Reprod. Dom. Anim. 40, 356 (abstract). KNECHT D, ŚRODOŃ S, SZULC K, DUZIŃSKI K, 2013. The effect of photoperiod on selected parameters of boar semen. Livestock Science 157(1), 364-371. http://dx.doi.org/10.1016/j.livsci.2013.06.027

KOZDROWSKI, R. AND DUBIEL, A. 2004. The effect of season on the properties of wild boar (Sus scrofa L.) semen. Animal Reproduction Science, 80(3-4), 281-289. http://dx.doi.org/10.1016/j.anireprosci.2003.08.006

KUNAVONGKRIT A., SURIYASOMBOON A., LUNDEHEIM N., HEARD T.W., EINARSSON S., 2005. Management and sperm production of boars under differing environmental conditions. Theriogenology 63(2), 657-667. http://dx.doi.org/10.1016/j.theriogenology.2004.09.039

LAWRENCE J. A., TURMAN E. J., RICH T., SHARP A., HILLIER J. C., 1970 A study of seasonal changes in boar semen. Oklahoma Agricultural Experiment Station No. M.P. 84 pp. $77-83$

MAUGET, R., 1982. Seasonality of reproduction in the wild boar. In: Cole, D.J.A., Foxcroft, G.R. (Eds.), Control of Pig Reproduction. Butterworths, London, pp. 509-526. http://dx.doi.org/10.1016/b978-0-408-10768-6.50029-0

MURASE T., IMAEDA N., YAMADA H., MIYAZAWA K., 2007. Seasona changes in semen characteristics, Composition of Seminal Plasma and Frequency of Acrosome Reaction Induced by Calcium and Calcium Ionophore A23187 in Large White Boars. J. Reprod. Dev; 53(4), 853-865. http://dx.doi.org/10.1262/jrd.19026

PARK C.S. and YI Y.J., 2002. Comparison of semen characteristics, sperm freezability and testosterone concentration between Duroc and Yorkshire boars during season. Anim. Reprod. Sci. 73(1-2), 53-61. http://dx.doi.org/10.1016/s0378-4320(02)00129-x

PELTONIEMI O.A.T., LOVE R.J., HEINONEN M., TUOVINEN V., SALONIEMI H., 1999. Seasonal and management effects on fertility of the sow: A descriptive study. Anim. Reprod. Sci. 55(1), 47-61. http://dx.doi.org/10.1016/s0378-4320(98)00159-6

PETROCELLI H., BATISTA C., GOSÁLVEZ J., 2015. Seasonal variation in sperm characteristics of boars in southern Uruguay. R. Bras. Zootec., 44(1), 1-7. http://dx.doi.org/10.1590/s1806-92902015000100001

SANCHO S., PINART E., BRIZ M., GARCIA-GIL N., BADIA E., BASSOLS J., KÁdÁR E., PRUNEDA A., BUSSAllEU E., YESTE M., COLL M.G., BONET S., 2004. Semen quality of postpubertal boars during increasing and decreasing natural photoperiods. Theriogenology, 62(7), 1271-1282. http://dx.doi.org/10.1016/j.theriogenology.2004.01.003

SCHNURRBUSCH U., WOLF G., SCHNEIDER F., GOTTSCHALK J., 2002. Jahreszeitlicher Verlauf der Konzentrationen von FSH, LH, Prolaktin, Testosteron und Östradiol-17ß sowie spermatologischer Parameter beim Eber. Tierärztl. Prax., 30, 244-251.

SCHULZE M., RUEDIGER K., MUELLER K., JUNG M., WELL C., REISSMANN M., 2013. Development of an in vitro index to characterize fertilizing capacity of boar ejaculates. Anim Reprod Sci., 140(1-2), 70-76. http://dx.doi.org/10.1016/j.anireprosci.2013.05.012

SMITAL J., 2009. Effects influencing boar semen. Anim. Reprod. Sci. 110(3-4) 335-346. http://dx.doi.org/10.1016/j.anireprosci.2008.01.024

SURIYASOMBOON A., LUNDEHEIM N., KUNAVONGKRITD A., EINARSSON S., 2004. Effect of temperature and humidity on sperm production in Duroc boars under different housing systems in Thailand. Livestock Prod. Sci., 89, 1-19. http://dx.doi.org/10.1016/i.livprodsci.2003.12.008

SYRING CLAUDIA, 2008. Einfluss von Jahreszeit, Rasse und Alter auf die Samenqualität beim Eber. Doctoral Thesis. University of Zurich.

TAST A., HALLI O., AHLSTROM S., ANDERSSON H., LOVE R.J., PELTONIEMI O.A.T., 2001. Seasonal alterations in circadian melatonin rhythms of the European wild boar and domestic gilt. J. Pineal Res., 30(1), 43-49. http://dx.doi.org/10.1034/j.1600-079x.2001.300106.x 